\title{
Zoonymic Peculiarity in Feature Cartoons for Children
}

\section{Особливості зоонімів у повнометражних мультиплікаційних фільмах для дітей}

\author{
Anastasiia Kuzmenko \\ Ph.D. in Philology, \\ Assistant Professor
}

\author{
Анастасія Кузьменко \\ кандидат філологічних наук, \\ доцент
}

E-mail: kuzunchik@email.ua orcid.org/0000-0003-1189-1438
Dnipropetrovsk State University
of Internal Affairs
$\triangle 26$, Gagarina Str., Dnipro,
Ukraine, 49000

\author{
Дніпропетровський державний \\ університет внутрішніх справ \\ $\triangle$ вул. Гагаріна, 26, Дніпро, \\ Україна, 49000
}

Original manuscript received July 27, 2018

Revised manuscript accepted August 30, 2019

\begin{abstract}
Objective. The object of studying is the English texts of feature cartoons for children, while its subject is psycholinguistic peculiarity of zoonyms in feature cartoon texts. The main goal of the research is to find out the psycholinguistic organization of zoonyms in the English language feature cartoons for children. The objectives are to classify zoonyms' origin, to differentiate sphere-sources and motivation of zoonym nomination, to highlight stylistic peculiarities of zoonyms.

Materials \& Methods. Specific methods and techniques are determined by the purpose and material to be analyzed, such as induction and deduction, analysis and synthesis, abstraction and concretization; longitudinal, processing and interpretation methods; psycholinguistic analysis; method of context-semantic analysis; the procedures of quantitative-qualitative calculations and the method of integral choice. Materials for the research are gathered from Paramount Pictures production, Dream Works animation, Universal Studio, Walt Disney production and the selection is the
\end{abstract}


English feature cartoons for children, such as 'The Lion King', 'Balto', 'Kung Fu Panda', 'Madagascar', 'Alpha and Omega', 'Shreck', 'Ferdinand', 'Puppy Dog pals', 'Ice Age' etc. Results. The article dwells upon the psycholinguistic aspect of zoonyms in the English language feature cartoons for children. In the sense of changing the direction of linguistics from language to speech and communication, it is impossible to consider linguistics excluding the anthropological factors such as mentality, culture, behaviour and development of a man individually and of mankind as a whole. In this paper, the ways of forming a world view of a man are presented, which is also formed by a linguistic world view, fauna is distinguished as an emerging element of knowledge influencing on human's cognition. Taking into account the fact that the world view about fauna is formed in the person's mind from the first days of life observing nature, listening to the lullabies, watching cartoons, the object of this study is feature cartoons for children, and the subject is zoonyms. In the course of the research, methods and techniques such as induction and deduction, analysis and synthesis, abstraction and concretization, the method of material sampling, quantitative calculation procedure are used to determine the frequency of this phenomenon usage. As a result, it is found that in the English language feature films for children, the names of the English, Scottish, Spanish, French, Italian, German, Chinese, Latin and Greek origins are used in zoonymy. Spheres-sources of zoonymy are multi-anthroponyms, single anthroponyms, toponyms, names of products, fitonyms and actual names of breeds and classes of animals. Nominative motivation is outlined by external features, behaviour, application of an animal, its breed and class. Stylistic peculiarities of zoonymy in the English language feature cartoons for children are such figures as the epithet, the metaphor, the personification and the euphony.

Conclusion. The article is the basis for further research in linguistics, anthropological linguistics, psycholinguistics, sociolinguistics, biovital linguistics and onomastics.

Key words: zoonym, feature cartoons for children, world view, language world picture, sphere-source, nominative motivation, stylistic peculiarity.

\section{Introduction}

Since the second part of the XX century, linguistics has changed the direction from studying language to studying speech and communication, as a language demonstrates itself in speech, which has its communicative aim. Thus, a human factor influences on a language. The object of anthropological linguistics is a linguistic identity that creates and receives texts, lives in the world of texts and forms under the influence of different texts of various genres.

Among texts of all genre variety a special place is taken by fiction heritage, which presents great experience and unlimited intelligence 
base of humanity. There are feature cartoons for children (FCC) among them. It is not coincidence that attention has been paid to texts for children in classic works (Piaget, 1969), by modern scientists (Egorova, 2015; Nakonechna, 2012), however the papers, which study FCC, are fragmental and they are concerned not to psycholinguistic, but psychological aspect. The absence of scientific researches on linguistic, especially psycholinguistic features of FCC, represents the current problem to investigate. The linguistic organization of texts attracts the attention of many researchers (Nakonechna, 2012; Ostapchenko, 2016) from different points of view: textual studies (McIntyre, 2012; Sandig, 2006), lingvo-psychology (Bakina, 2003; Belousov et al., 2005), cognitive linguistics (Semenenko, 2015; Semino \& Short, 2004; Stockwell, 2002), psycholinguistics (Cremers \& Chemla, 2016; Cock \& Arias, 2018; Elkonin, 2007; Griffiths \& Görsev, 2016; Goncharova, 2017; Guts, 2005; Kholod, 2017; Leontyev, 2003; Piaget, 1969; Rakosi, 2017; Yanovets, 2014; Zalevskaya, 2005, 2014).

Taking into consideration the full size of FCC sphere, it is decided to research zoonyms in FCC texts on the basis of the English language as there are more and more cartoons with animals as the main characters and their names (nicks) are one of the most memorable types of the cartoon text.

The current relevance of the article is determined by the anthropocentrism of the modern linguistic paradigm and by the general tendency of the humanitarian type of knowledge to the psycholinguistic, sociocultural, psychological, gender and biovital study of speech activity, within the direction of modern linguistics - psycholinguistic analysis of text communication with its increased interest in the linguistic world view, the valuable orientations of the ethnos, including age differentiation.

The object of studying is the English texts of feature cartoons for children, while its subject is psycholinguistic peculiarity of zoonyms in FCC texts on the basis of the English language as a language world view forming element.

The main goal of the research is to find out the psycholinguistic organization of zoonyms in the English language feature cartoons for children. The objectives are to classify zoonyms' origin, to differentiate sphere-sources and motivation of zoonym nomination, to highlight stylistic peculiarities of zoonyms. 


\section{Methods and Techniques of the Research}

Scientists from different schools investigated the issues of developing a comprehensive methodology for psycholinguistic analysis (Cremers \& Chemla, 2016; Rakosi, 2017). Specific methods and techniques are determined by the purpose and material to be analyzed, and are based on general scientific methods of induction and deduction, analysis and synthesis, abstraction and concretization. The lingvopsychological approach to this problematic study has led to selection of methods such as longitudinal (for monitoring the components of speech activity in the FCC), processing and interpretation (for the input of statistical data and description). Lingvopragmatic and psycholinguistic analysis help to understand the level of influence of paralinguistic components on the target audience; method of context-semantic analysis helps to understand zoonym nature in a text surrounding and to identify psycholinguistic specificity more properly. In addition, the procedures of quantitative-qualitative calculations have been used to determine the frequency of the described phenomena, and the method of integral choice - for the purpose of the correct research results.

Materials for the research are gathered from Paramount Pictures production, Dream Works animation, Universal Studio, Walt Disney production and the selection is the English feature cartoons for children, among which there are 'The Lion King', 'Balto', 'Kung Fu Panda', 'Madagascar', 'Alpha and Omega', 'Shreck', 'Ferdinand', 'Puppy Dog pals', 'Ice Age' etc.

The scientific novelty of the work is determined by the place and the role of zoonyms in the English language FCC texts which are first defined as a language world view forming element, and the types of the zoonyms, their stylistic peculiarities and psycholinguistic effect on children's mind are characterized.

\section{Results and Discussions}

Studying every language phenomenon is worth using it - in the text, and the cognitive approach must be supplemented by observation of functioning forms and the creation of the new ones. However, there 
are frameworks in cognitive sociolinguistic and ethnocultural studies (Fairclough, 1995; Schiffrin, 1994) and in cognitive pragmalinguistics (Carston, 2002), strategies should be expanded taking into account the mental processes of speech personality. The language encodes the historical (cultural) memory of both humanity as a whole, and of a person in particular (Humboldt, 1985); there are different world views of different native speakers - nature is divided in the direction that our native language is presented (Sapir, 1993).

World view is interpreted as a general idea of the world and its structure; types of objects, their correlation and world views are distinguished by the degree of universality and means of modeling reality (Ivanova, 2015). The world view exists in a vague and undifferentiated form of consciousness. From a psychological point, the world view is a set of knowledge that provides integrated understanding (scientific, theoretical) of those complex processes that occur in nature, society and a person itself (Ivanova, 2015). As for A. Leontyev (2003), our attitude and understanding of the world is formed by words of native language. It means that lots of notions of any phenomenon of reality will create a specific view of an individual, which will be gathered into a complex system that is called a world view in psycholinguistics.

The world view under its display in a language is more complex and deeper than the one reproduced by its own name. It is also a view of relations and relations that exist, firstly, between the objects (phenomena, situations); secondly, between the objects (phenomena, situations) and those who perceive and appreciate them; and thirdly, between classifications and estimations. In other words, the concept of 'world view' includes not only knowledge of the objects and non-substantive entities, but also knowledge of the moral norms and spiritual values of the language community, causal relationships, ethnical norms, experience of previous generations etc (Bondarenko, 2003). Following A. Leontyev (2003), who states that any fragment of the world is associated with the human psyche mediation of surrounding reality with the help of subject values, design in the form of cognitive schemes, and sensory experience through reflection. The world view is also considered as a product of mental activity, which is actualized on the basis of a holistic lexicalsemantic system of language; knowledge gained by a man through both his/her own and social experience. 
The language is the most important way of forming and maintaining human knowledge of the world. The language world view (LWV) is a mosaic-like system of interconnected language units that reflects a relatively objective state of the environment and the inner world of each man that is, in general, the world view represented by a complex system of phonetic phenomena, lexical-semantic and grammatical meanings, as well as stylistic characteristics. Both conceptual and linguistic world views can be perceived as a human universe and as a national language phenomenon. Each language forms a chaotic system that is reflected in the minds of its speakers and creates an appropriate LWV, which is traditionally understood as a set of knowledge about the world reflected in the language, as well as ways of obtaining and interpreting new knowledge (Ivanova, 2015). LWV is an interpretation of reality on the basis of not only individual and collective experience, but also nominations, the peculiarities of their functioning (Kubriakova, 1997).

LWV of a child is qualified as positive and concrete, where the first one is associated with certain well-established norms of communication and the second one is conditioned by the peculiarity of the child's mental development, its visual-action thinking and concretized notions of the world.

LWV is a combination and collaboration of sounds, meanings and notions. The relation between sounds and meanings can be explained by native speakers based on facts of linguistic and extra-linguistic reality (Blinova, 2007). This phenomenon contains designated, recognized by the speakers sign in its internal form, that is the basis of the nomination. Thus, nominations are fixed in the motivational meaning of words as a result of comprehension of the surrounding reality by native speakers and these nominations reflect the way of semantic division of the conceptual model of the world (Filatova, 2002). Certain linguistic units that are completely or partially unconsciously processed by the human brain are actualized in the speech (Yanovets, 2014)

As fauna is a perceptual base of creation of the world view, it is essential to investigate its nominations in LWV. It cannot be denied that in a modern world the role of animals is great as they are used as domestic pets, helpful servants (for example, dogs for blind people etc.), assistants in psychological and medical treatment. Of course, a special role is played by the rescue animals not only during the war, but also during peacetime. It is also difficult to imagine our life without a circus, 
a zoo and various exhibitions. In most cases, all our 'smaller brothers' have their names which describe animals' peculiarity / individual feature, which is the object of zoonymy.

Zoonymy is the youngest area of onomastics which deals with the proper names of animals, their nicknames. This is a poorly researched scientific layer, which is probably represented due to the rare fixation of zoonyms in official documents and due to the death of their bearer. Zoonyms represent a very interesting layer of lexicology, where interrelations between the language and the mentality of the individual and ethnos are clearly revealed.

It should be noted that the investigated language units used in FCC are not only English, but also borrowed zoonyms. It can be explained by the place of cartoon production, as most of the English language movies and cartoons are produced in Hollywood that is the territory of the United States of America which is the country of different nationalities, where cultural integration is an evident point for it. This way children's mind is fulfilled with the knowledge of ethnic equality. Moreover, choosing a favourite character with a name of non-native origin means that on psychological level a person will remember his/her attitude to representatives of other nations. Thus, any person will behave the same way in adult age, demonstrating tolerance and respect to other nations due to psycholinguistic and extralinguistic aspect. Thus, FCC proposes multiple choice of foreign names. In feature cartoons for children animals' nicknames - zoonyms of European origin $(66.0 \%)$ are widely used. For instance, Mason, Jackie, Mort, Gia, Ted are of the English origin (Felomena, 2018); Quinty McSquinty is the Scotish one, Rico is Spanish and Maurice is French while Stephano, Lucita, Guapo are Italian, Rolly - German. There are some zoonyms which are of ancient European origin (Felomena, 2018) found in FCC: Florie, Marty, Rufus - Latin; Vitaliy - ancient Rome origin; Phil, Maya, Sonya, Boris - ancient Greek (Felomena, 2018). Also, a lot of Asian names $(34.0 \%)$ in FCC, mainly represented by Chinese zoonyms: Shifu, Po Ping, Yao, Chao, Shengqi, Mugan, Lun, Tai Lung, Kai, Qinchu, Kuo (Felomena, 2018).

Sometimes zoonyms of rarely used language origin can be come across. For instance, Rafiki and Sarabi are of the Swahili language, Mufasa is of the Manazoto language. In such a way due to psycholinguistic influence children's mind creates some mysterious 
vision of the characters with unusual names; their imagination / mind evaluates the power of the character, hyperbolizes its features and traits.

Thus, we can state that feature cartoons for children show wide choice of zoonyms of different origins. On psychological level this linguistic method makes a person / a child be tolerant and friendly to each nationality, live, interact and communicate together. Also a child realizes rules of behavior in situations of interaction with other people, understanding the language of communication, determined by the stereotype of a certain cultural community (Kulikovskaya, 2002).

Among the sphere-sources of zoonyms' word-building such spheres as multi-anthroponyms, singular anthroponyms, toponyms, astronomers, names of products, fitonyms and fauna can be distinguished.

In the English speech in FCC there are widely used derivatives of multi-anthroponyms - their shortened forms (43.0\%): Mag, Sam, Ben, Ted, Alex, Phil etc. and diminutive forms with suffix $-y$ or $-i e(57.0 \%)$ : Molly, Dallie, Whaley, Dalley, Nicky, Jackie, Maggie, Hedgie and so on. The child's psyche is formed the way that the child correlates with all actions of any fiction character. "A child does not sympathize with a character, but rather feels like this character» (Kon, 1975: 65). That explains the presence of real people's names as zoomyns. The usage of diminutive suffixes $-y$ or $-i e$ has psycholinguistic influence, as it is associated with tenderness of all mothers to call their children in such a way. Thus, hearing diminutive form of any animal's name a child has an ordinary reaction - love, delicacy, careful attitude to the character.

Sphere-source Singular anthroponyms, represented by the names of famous doers of the past and present times, popular literature characters, myth heroes and others, are illustrated as Puss in Boots, Three Little Pigs, Three Blind Mice, The Big Bad Wolf etc.

Sphere-source Toponym in FCC zoonymy is not frequent, it is found just in such animal's nickname as Sidney (Sid), however astronomers are a common thing here: Stella, Alpha, Omega etc. Toponymic and astronomic sphere-sources improve child's imagination and creativity, as it bears fantasy about unreality and inscrutability of unknown and inaccessible things.

Name of products is also used as a sphere-source for animals' nicknames: Cupcake, Sweety, Peaches and others. According to A. Zalevskaya (2014) perceptual and cognitive processes are inseparable from emotional and evaluative experiences, so here is no nickname with 
salty, sour or bitter product element in nomination, which also influences child's psyche. Children prefer eating something tasty and sweet like fruit and candies. This way mind cannot reject the character with the name containing an element of lovely dish.

Sphere-source Fitonym is demonstrated in the feature cartoons for children in such zoonyms as Rolly, Rosy, Daisy, Lily and so forth. However, the main peculiarity of zoonym-building in the English language feature cartoons for children is sphere-source Fauna. For example, Guard Dog, Single Squirrel, Master Tigress, Master Bul, Master Frog, Wolf Boss, Dancing Dog, Donkey etc.

Despite the fact, that among zoonym sphere-sources scientists identify such spheres as Computer slang and other Proper names, they are not found in the texts of animals' nicknames in the English language FCC.

A nominative attribute is a recognizable peculiarity of the designation, which lies in the base of its nomination and is expressed in a word either directly or indirectly/associatively (Blinova, 2007). If the description of a set of nominative features which is the characteristic of a certain thematic group of words carries information about the peculiarities of the perception of the surrounding reality by the language collective, the idea of fixing this information in the language gives an investigation of the motivations in nomination.

Despite the coordination improvement of the body parts mobility and knowledge of the body; improvement of large motility skills, transition to internal, mental; development of orientation in space and time; assimilation of norms and forms of behaviour; appearance of moral features of personality in communication; the formation of high feelings (Yashkova \& Suhareva, 2009), external practice of child's perceptive actions cannot be denied.

Studying zoonyms in the English language feature cartoons for children some characteristic groups of nominative motivation can be defined. They are related to: 1) the appearance of animals; 2) the features of their behaviour; 3) application of an animal; 4) animal's breed/class.

In the content of zoonyms' nominative motivation associated with the appearance of animals, it is possible to identify the aspects embodied in the following principles of nomination: 
1.1) colour: Master Golden Takin, Snow Leopard, White Wolf etc;

1.2) size: Big Bad Wolf, Little Pigs etc;

1.3) parts of body: Kitty Softpaws etc.

Nominative motivation subgroups associated with the peculiarities of form, structure of skin of an animal are not typical for zoonyms in the English language FCC.

Nominative motivation associated with the specifics of animal behaviour, are specified in the principles of nomination:

2.1) feature: Speedy the Snail, Blind Mice etc;

2.2) action: Bark Knight, Dancing Dog, Master Flying Rhino etc.

3. Nominative motivation associated with application of animals: Guard Dog etc.

4. Nominative motivation associated with animal's breed/class: Captain Dog, Hedgie, Whaley, Bizzy the Beaver, Strider the Sheepdog, Single Squirrel, Grizzly Bear.

Nominative motivation associated with animals' way of life (place, time/period of living), animals' nourishment, emitted sounds, the smell of an animal is untypical for zoonyms in the English language FCC.

Being a fiction product any feature cartoon for children is the art, which uses lots of stylistic means. The alive language undergoes a certain artistic transformation, resulting the fact that a system of a new language appears as a superstructure above the natural language, and the same is in FCC.

The words of any language are characterized not only by lexical meanings and grammatical features, but also stylistically, that is the sphere and frequency of use, attribution to a certain style, emotional colour or its absence (Burke, 2006).

In order to increase the expressive-emotional effect of expression, language means are widely used. The common means in such situations are stylistic figures. There are many definitions of stylistic figures, but they are indicated as the means of expression, based on a combination of linguistic units in the text that have been investigated by a number of scientists (Cremers \& Chemla, 2016; Griffiths \& Görsev, 2016; McIntyre, 2012; Morini, 2013; Yanovets, 2014 and others).

The figures of addition are methods of combining the meanings of units of different levels (Brandes, 2004). Insignificant objects of everyday life become interesting and unusual for the recipient (a child) 
by using epithets in FCC, which are the artistic definition of objects, phenomena, situations, which separate, emphasize, and increase the existence of a definite feature/trait of an object that can update a certain meaning of the word. The usual things that do not attract attention are disclosed from another point of view and imprint the beauty of simplicity: Dancing Dog, Single Squirrel, Big Baboon, Big Bad Wolf, Blind Mice.

The epithets endow zoonyms with their individual characteristics, providing a pictorial, expanding the secret meaning or appreciation of the addressee, creating an emotional mood throughout the English language feature cartoons for children. Taking into account the fact that a child recognizes new objects of the surrounding environment every day, the specific qualities inherent in the zoonym are the most valuable images in the infant imagination. So, zoonyms are distinguished with the help of colour, shape and type of behaviour.

Figures of substitution belong to methods of stylistic expressiveness (Brandes, 2004). They are represented in the English language feature cartoons for children mainly by the metaphor $(15.0 \%)$ such as Snowflake, Sweety and the personification (85.0) like Mr. Chew, King Julien XIII.

The metaphor is an important mean of representing and comprehending of reality (Lakoff, 2003) by using the word in the figurative sense to emphasize the similarity of certain features. The purpose of the metaphor in the FCC is to enhance the image of attraction of zoonyms, that is to make it more interesting and more entertaining: Cupcake, Daisy, Snowflake. The metaphor forces to draw attention to a certain similarity (often new, unexpected) between two or more objects (Deignan, 2013). Observation allows us to make some generalizations about the role and the place of the metaphor in the FCC zoonymy, namely, by perceiving it, a child seeks to distinguish several objects of a certain set, to find common and distinctive features in them, to emphasize their similarity to one or another sign. All this stimulates not only the development of aesthetic taste, but also intellectual abilities. The metaphor, even in zoonyms, performs the function of creating multilevel meanings that require creative efforts on the part of the recipient.

The figurative basis, which forms the associative plan of the English zoonyms, most often refers to the semantic sphere of 'animal'. 
In addition to metaphorical attitudes, the personification is the characteristic of zoonyms in FCC - stylistic figure that gives an idea of any concept or phenomenon by portraying it as a living person endowed with the features of this concept. The personification is a presentation of natural phenomena, human qualities, concepts in the image of a person (Summers, 2006). Thus, it is possible to distinguish the groups of zoonymic personification containing the information about:

a) profession: Captain Dog, Guard Dog, Master Crane, Master Antelope, Master Monkey, Wolf Boss, Boss Beaver;

b) royal status: Lord Shen, Duke Meerkat, Mufasa (means 'king' in the Manazoto language), King Julien XIII, Bark Knight, Duke;

c) family name: Quinty McSquinty, Melman Mankiewicz, Kovalski, Boris Goosinov;

d) gender: Okapi Girl;

e) family relations: Badger Twins, Wu Sisters, Uncle Max, Granny;

f) social status: Mr. Chew, Mr. Yeung, Mrs. Gav.

The personification is the most important stylistic mean of the FCC zoonyms, because everything that surrounds a child is filled with human skills and abilities.

The sound organization is engaged in a separate section of stylistics - phonics. The phonics gives an assessment of the sound structure peculiarities of the language, defines the conditions of euphony characteristic, examines the phonetic techniques of expressiveness of the speech, and teaches the most perfect artistic and stylistic sound expression of thoughts (Pleschenko, 20017). The sound expressiveness of the language lies primarily in its euphoria, harmony, use of rhythm, rhyme, alliteration, assonance and other means.

Sound semantics plays a special role in zoonyms. A certain correlation between a sound and a meaning, that is the audio-content interrelation, is not incorporated into the language system; it only arises with the text and is occasional. Zoonyms of FCC are usually connected with the animal nomination: Hedgie - hedgehog, Whaley whale, Dallie - Dalmatian, Cheetato and Cheetata - cheetahs, Boris Goosinov - goose etc.

Despite the fact that the phonetic system of the language is the most distant from the content, the sound of zoonyms plays a decisive role in FCC. 


\section{Conclusions}

Fauna takes one of the most prominent places in the world view of any nation as it surrounds people from their first days of life. Children get acquainted with animals in different ways: playing outdoors, having pets and watching cartoons with animals as the main characters. Zoonyms in feature cartoons for children demonstrate one of the most interesting ways to introduce the language world view of a nation (namely English-speaking society). While investigating zoonyms it has been defined their origins such as English, Scotish, Spanish, French, Italian, German, Latin, Greek, Chinese and Russian.

Also, it has been researched the main sphere-sources of zoonym nomination. They are multi-anthroponyms, singular anthroponyms, toponyms, astronomers and names of products, fitonyms and fauna.

The most common point is the zoonyms' nominative motivation, associated with the appearance of an animal, which is specified in the nominations of colour and form. Also, zoonyms, based on nominative motivation, associated with animals' breed, are frequent. In the course of the study, a number of animal names of the English language in FCC have been found with the identification of their special behaviour and application of animals. Nominative motivation which is associated with animals' way of life, its nourishment, emitted sounds and smell is not typical for zoonyms in the English language feature cartoons for children.

There are such stylistic dominants of zoonyms in the English language feature cartoons for children described as the epithet, the metaphor, the personification and the euphony.

To conclude, zoonyms in the English language feature cartoons for children is a wide sphere to research in various fields of study such as cognitive linguistics, functional psycholinguistics, linguistics, social linguistics, ethnolinguistics, semantics, onomastics and others.

\section{References}

Bakina, T. (2003). Literatura dlia ditey u konteksti kultury dytynstva [Literature for children in childhood context]. Mandrivets - Traveller, 5, 44-47 [in Ukrainian].

Belousov, A.F., Golovin, V.V., Kuleshov, E.V., \& Lure, M.L. (2005). Detskiy folklor: itogi i perspektivi [Children folk: results and perspectives]. Pervyiy Vseross. 
kongress folkloristov - The first Cross-Russian congress of folklorists, 1, 215-242 [in Russian].

Blinova, O.I. (2007). Motivologiya i eyo aspekty [Motivology and its aspects]. Tomsk: Tomsk university [in Russian].

Bondarenko, O.S. (2003). Pro spivvidnoshennia mizh movnoyu ta konceptualnoyu kartynamy svitu [The relation between the language and conceptual pictures of the world]. Naukovi zapiski Luganskogo nacionalnogo pedagogichnogo universitetu - Scientific notes of the Luhansk National Pedagogical University, 4(1), 37-44 [in Ukrainian].

Brandes, M.P. (2004) Stilistika teksta [Stylistics of the text]. Moscow: 'Progresstraditsia' [in Russian].

Burke, M. (2006). Emotion in Stylistics. Encyclopedia of Language and Linguistics, 2, 127-129. https://doi.org/10.1016/B0-08-044854-2/00508-3

Carston, R. (2002). Linguistic Meaning, Communicated Meaning and Cognitive Pragmatics. Mind and Language, 17(1-2), 127-148. https://doi.org/10.1111/14680017.00192

Cock, De B., \& Arias, C.G. (2018). Reference to Self and Other in the Digital Public Sphere: The Case of Political Blogs. Journal of Psycholinguistic Research, 47(2), 343-354. https://doi.org/10.1007/s10936-017-9537-4

Cremers, A., \& Chemla, E.A. (2016). Psycholinguistic Study of the Exhaustive Readings of Embedded Questions. Journal of Semantics, 33(1), 49-85. https:// doi.org/10.1080/10489223.2016.1176173

Deignan, A. (2013). Metaphor, genre and recontextualization. Metaphor and Symbol, 28(1), 41-59. https://doi.org/10.1080/10926488.2013.742842

Egorova, A.A. (2015). Zvukoizobrazitelnost $v$ tradicionnoj anglijskoj detskoj poehzii (na materiale Nursery Rhymes) [Soundscapes in traditional English children's poetry (based on Nursery Rhymes)]. Ivanovo [in Russian].

Elkonin, D.B. (2007). Detskaya psihologiya [Child's psychology]. Moscow: Akademiya [in Russian].

Fairclough, M. (1995). Critical Discourse Analysis. The Critical Study of Language. London \& New York: Longman.

Felomena, (2018). Jurnal o nepoznannom [Journal about unknown]. Retrieved form https://felomena.com/imena/ [in Russian].

Filatova, A.S. (2002). O nekotoryh aspektah otrazheniya yazykovoj kartiny mira $\mathrm{v}$ motivirovannoy leksike russkogo i angliyskogo yazykov (na materiale ornitonimov) [Some aspects of the reflection of the linguistic picture of the world in the motivated vocabulary of the Russian and English languages (on the material of the ornithonyms)]. Kartina mira: modeli, metody, koncepty: materialy Vseros. mezhdisciplinarnoj shkoly molodyh uchenyh 'Kartina mira: yazyk, filosofiya, nauka' - The picture of the world: models, methods, concepts: materials of Cross-Russian interdisciplinary school of young scientists 'The Picture of the World: Language, Philosophy, Science' (pp. 255-260) [in Russian].

Goncharova, T. (2017). Zhanrovi transformatsii dyskursu futbolnyh fanativ: psyholingvistychnyj pidhid [Genre transformations of the Football Fans Discourse: Psycholinguistic Mechanisms], Psyholingvistyka - Psycholinguistics, 22(2), 12-27 [in Ukrainian].

Griffiths, C., \& Görsev, I. (2016). Styles and Style-Stretching: How are They Related to Successful Learning? Journal of Psycholinguistic Research, 3(45), 599-613. https://doi.org/10.1007/s10936-015-9366-2 
Guts, Ye.N. (2005). Psiholingvisticheskoye issledovaniye yazykovogo soznaniya podrostka [Psycholinguistic study of the language consciousness of a teenager]. Omsk: Variant-Omsk [in Russian].

Humboldt, V. (1985). Harakter yazyka i harakter naroda [Nature of language and people's character]. Yazyk i filosofiya kultury - Language and Philosophy of Culture (pp. 370-381). Moscow: Progress [in Russian].

Ivanova, O.V. (2015). Movna kartina svitu yak vidobrazhennya movnoi svidomosti osobystosti [Language picture of the world as a reflection of the linguistic consciousness of the individual]. Naukovi zapiski nac. un-tu 'Ostroz'ka akademiya' - Scientific Notes of National Un-ty of 'Ostroh Academy', 51, 36-39 [in Ukrainian].

Kholod, A. (2017). Psyholingvisticheskaya eksplikatsiya verbalnoy agressii [Psycho-Linguistic Explication of Verbal Aggression]. Psyholingvistyka Psycholinguistics, 22(2), 113-126 [in Ukrainian].

Kon, I. (1975). Kakimi oni sebya vidyat? [How do they see themselves?]. Moscow: Znanie [in Russian].

Kubriakova, E.S. (1997). Vidy prostranstva, teksta i diskursa [Types of space, text and discourse]. Kategorizaciya mira: prostranstvo i vremya - Categorizing the world: space and time (pp. 19-20). Moscow [in Russian].

Kulikovskaya, I.E. (2002). Stanovlenie mirovideniya detey doshkolnogo vozrasta $v$ kontekste kulturyi [Creation of world vision of preschoolers in cultural context]. Moscow: Prosveschenie [in Russian].

Lakoff, G. (2003). Metaphors we live by. London: The university of Chicago press. https://doi.org/10.7208/chicago/9780226470993.001.0001

Leontyev, A.N. (2003). Osnovy psikholingvistiki [Fundamentals of psycholinguistics]. Moscow : Smysl / St. Petersburg: Lan [in Russian].

McIntyre, D. (2012) Corpus stylistics in the classroom. In M. Burke (Eds), Pedagogical Stylistics (pp. 113-125). London: Continuum.

Morini, M. (2013). Towards a musical stylistics: Movement in Kate Bush's 'Running Up That Hill'. Language and Literature, 283-297. https://doi. org/10.1177/0963947013491486

Nakonechna, Yu.S. (2012). Movni zasobi konceptulizatsii svitu v anglomovnih virshovanih tvorah dlya ditej [Language means of conceptualization of the world in English-language poetic works for children]. Candidate's thesis. Kyiv: T. Shevchenko Kyiv national un-ty [in Ukrainian].

Ostapchenko, V.O. (2016). Tipi Implikatur u poetichnomu diskursi R.M. Rilke [Types of implications in poetic discourse of R.M. Rilke]. Naukoviy visnyk Shidnoevrop. nats. un-tu im. Lesi Ukrainki - Scientific journal of Lesia Ukrainka SouthEuropean national university, 6(331), 126-130 [in Ukrainian].

Piaget, Zh. (1969). Izbrannye psihologicheskie trudy [Selected psychological works]. Moscow [in Russian].

Pleschenko, T.P. (2001). Stilistika $i$ kultura rechi [Stylistics and culture of speech]. Minsk: Tetra Systems [in Russian].

Rákosi, C. (2017). Replication of Psycholinguistic Experiments and the Resolution of Inconsistencies. Journal of Psycholinguistic Research, 46(5), 1249-1271. https:// doi.org/10.1007/s10936-017-9492-0

Sandig, B. (2006). Textlinguistik des Deutschen. Studienbuch. Berlin \& New York: de Gruyter [in German]. 
Sapir, E. (1993). Izbrannye trudy po yazykoznaniyu i kulturologi [Selected works on linguistics and cultural studies]. Moscow: Progress [in Russian].

Schiffrin, D. (1994). Approaches to Discourse Oxford: Blackwell.

Semenenko, L.L. (2015). Politichna kartina svitu: kriteriï viokremlennya [Political picture of the world: selection criteria]. Naukovi zapiski nats. un-tu "Ostrozka akademiya» - Scientific Notes National university 'Ostroh Academy', 51, 87-89 [in Ukrainian].

Semino, E., \& Short, M. (2004). Cognitive Stylistics: Language and cognition in text analysis. Linguistic Approaches to Literature. London: Taylor \& Francis.

Stockwell, P. (2002). Cognitive Poetics: an Introduction. London \& New York: Routledge.

Summers, D. (2006). Longman Dictionary of Contemporary English. London: Pearson Longman.

Yanovets, A. (2014). Psycholinguistychni Osoblyvosti Dyskursu Anglomovnoho Polityka u Stani Emotsiynoyi Napruhy [Psycholinguistic Features of English Speaking Politician's Discourse in the State of Emotional Stress]. Extended abstract of candidate's thesis. Kherson: Kherson State University [in Ukrainian].

Yashkova, A.N., \& Suhareva, N.F. (2009). Vozrastnaya psihologiya [Age-oriented psychology]. Moscow: Progress [in Russian].

Zalevskaya, A.A. (2005). Psiholingvisticheskie issledovaniya [Psycholinguistic research]. Moscow: Gnozis [in Russian].

Zalevskaya, A.A. (2014). Interfeysnaya teoriya znacheniya slova: psikholingvisticheskiy podkhod [Interface theory of the meaning of the word: psycholinguistic approach]. Tver: TGU [in Russian].

\section{АНОТАЦІЯ}

Мета дослідження. Об'єктом вивчення послугували англомовні тексти мультиплікаційних фрільмів для дітей, а предметом - психолінгвістичні особливості зоонімів у мультиплікаційних фільмах. Головна мета - з'ясувати психолінгвістичну організацію зоонімів у англомовних мультиплікаційних фільмах для дітей. Задачі - класифікувати зооніми щодо за їх походженням, диреренціювати за сферою-ресурсом у номінації, визначити номінативну мотивацію та змалювати стилістичну специфіку.

Методики дослідження. Методи та техніки зумовлені метою дослідження та матеріалом для вивчення, серед яких методи індукції та дедукції, аналізу та синтезу, абстракції та конкретизації; лонгітюдний та інтерпретаційний методи; психолінгвістичний аналіз; метод контекстуально-семантичного аналізу; прочедура кількісно-якісних підрахунків та метод вибірки. Матеріали для дослідження дібрані з Paramount Pictures фільмовидавництва, Dream Works анімації, Universal cmудіï, Walt Disney видавництва та селекції англомовних мультиплікаційних фрільмів для дітей, як 'The Lion King', 'Balto', 'Kung Fu Panda', 'Madagascar', 'Alpha and Omega', 'Shreck', 'Ferdinand', 'Puppy Dog pals', 'Ice Age' momo.

Результати. Статтю присвячено психолінгвістичному аспекту зоонімів в англомовних повнометражних мультиплікаційних фільмах для дітей. 3 причини 
зміни напрямку лінгвістики від безпосередньо мови до мови і комунікації, неможливо розглядати лінгвістику, виключаючи антропологічний фактор: менталітет, культура, виховання та розвиток як людини індивідуально, так і людства в цілому. У даній роботі представлені шляхи фрормування картини світу людини, а також вплив мовної картини світу, фауна виділяється як формотворчий елемент знань. 3 огляду на той фрактор, що картина світу щодо фрауни утворюється у людини з перших днів життя, спостерігаючи природу, слухаючи колискові, переглядаючи мультфільми, об'єктом дослідження послужили повнометражні мультиплікаційні фільми для дітей, а його предметом - зооніми. У ході дослідження застосовано такі методи і техніки, як індукція і дедукція, аналіз і синтез, абстракція $і$ конкретизація, процедура кількісного підрахунку для визначення частоти вживання феномена, метод вибірки матеріалу. В результаті було встановлено, що у зоонімів в англомовних повнометражних фрільмах для дітей використовуються клички англійського, шотландського, іспанського, французького, італійського, німецького, китайського, латинського та грецького походження. Сферамиджерелами утворення зоонімів слугують мультіантропоніми, поодинокі антропоніми, топоніми, назви продуктів, фітонімів і власне назви порід / класів тварин. Номінативна мотивація окреслена зовнішніми ознаками, поведінкою, призначенням і породою / класом тварини. Стилістичними особливостями зоонімів англомовних повнометражних мультиплікаційних фрільмів для дітей $\epsilon$ такі фрігури, як епітет, метафора, персоніфікація й еуфонія.

Висновки. Стаття являє собою основу для подальших досліджень в лінгвістиці, антропологічній лінгвістиці, психолінгвістиці, соціолінгвістиці, біовітальній лінгвістиці та в ономастиці.

Ключові слова: зоонім, повнометражний мультиплікаційний фільм для дітей, картина світу, мовна картина світу, сфера-ресурс, номінативна мотивація, стилістичні властивості.

\section{Кузьменко Анастасия. Особенности зоонимов в полнометражных мультипликационных фильмах для детей}

\section{АННОТАЦИЯ}

Цель исследования. Объектом изучения стали англоязычные тексты мультипликационных фильмов для детей, а предметом психолингвистические особенности зоонимов в мультфильмах. Основная цель установить психолингвистическую организацию зоонимов в англоязычных мультипликационных фильмах для детей. Задачи - классифицировать зоонимы относительно их этимологии, дифференциировать по сфере-ресурсу при номинации, определить номинативную мотивацию и описать стилистическую специфику.

Методики. Цели и материалы исследования обусловили методы и техники, среди которых методы индукции и дедукции, анализа и синтеза, абстракции и 
конкретизации; лонгитюдный метод и интерпретация; психолингвистический анализ; метод контекстуально-семантического анализа; процедура количественно-качественных подсчетов и метод выборки. Материалы для исследования подобраны из Paramount Pictures фильмопроизводства, Dream Works анимации, Universal cmудиu, Walt Disney производства и селекции англоязычных мультфильмов для детей, таких как 'The Lion King', 'Balto', 'Kung Fu Panda', 'Madagascar', 'Alpha and Omega', 'Shreck', 'Ferdinand', 'Puppy Dog pals', 'Ice Age' u m.d.

Результаты. Статья посвящена психолингвистическому аспекту зоонимии в англоязычных полнометражных мультипликационных фильмах для детей. В виду изменения направления лингвистики от непосредственно языка к речи и коммуникации, невозможно рассматривать лингвистику, исключая антропологический фактор: менталитет, культура, воспитание и развитие человека индивидуально и человечества в челом. В данной работе представлены пути формирования картины мира человека, а также влияние языковой картины мира, выделяется фрауна как формирующийся элемент знаний. Учитывая тот фактор, что картина мира относительно животного мира фрормируется у человека с первых дней жизни, наблюдая явления природы, слушая колыбельные, просматривая мультфильмы, объектом исследования послужили полнометражные мультипликационные фильмы для детей, а его предметом - зоонимия. В ходе исследования применены такие методы и техники, как индукция и дедукция, анализ и синтез, абстракция и конкретизация, прочедура количественного подсчета для определения частоты употребления феномена, метод выборки материала. В результате было установлено, что в зоонимии в англоязычных полнометражных фильмах для детей используются клички английского, шотландского, испанского, французского, итальянского, немецкого, китайского, латинского и греческого происхождения. Сдерамиисточниками образования зоонимов служат мультиантропонимы, единичные антропонимы, топонимы, названия продуктов, фитонимы и собственно названия пород и классов животных. Номинативная мотивация очерчена внешними признаками, поведением, предназначением и породой / классом животного. Стилистическими особенностями зоонимии англоязычных полнометражных мультипликационных фильмов для детей являются такие фигуры, как эпитет, метафора, персонификация и эуфония.

Выводы. Статья представляет собой основу для дальнейших исследований в лингвистике, антропологчческой лингвистике, психолингвистике, социолингвистике, биовитальной лингвистике и ономастике.

Ключевые слова: зооним, полнометражный мультфильм для детей, картина мира, языковая картина мира, сфрера-ресурс, номинативная мотивация, стилистические свойства. 